\title{
Bacillus subtilis and Bacillus licheniformis reduce faecal protein catabolites concentration and odour in dogs
}

\author{
Tais Silvino Bastos ${ }^{1 *}$, Daniele Cristina de Lima', Camilla Mariane Menezes Souza', Alex Maiorka', \\ Simone Gisele de Oliveira ${ }^{1}$, Letícia Cardoso Bittencourt ${ }^{2}$ and Ananda Portella Félix ${ }^{1}$
}

\begin{abstract}
Background: Direct-fed microbials (DFM), such as Bacillus subtilis and Bacillus licheniformis, may improve gut functionality of the host by favouring non-pathogenic bacteria and reducing the formation of putrefactive compounds. The aim of this study was to assess the nutrient digestibility, faecal characteristics and intestinalfermentation products in dogs fed diets with Bacillus subtilis and Bacillus licheniformis. Sixteen dogs were randomly divided into two groups. Every eight dogs were fed with the control diet or the diet with the addition of $62.5 \mathrm{~g}$ of DFM (B. subtilis and B. licheniformis)/ton. Diets were provided throughout a 20-day adaptation period, followed by 5 days of total faecal collection. Nutrient digestibility and the metabolisable energy of the diets, plus the dogs' faecal characteristics and intestinal fermentation products were assessed.
\end{abstract}

Results: There were no differences in nutrient digestibility $(P>0.05)$. However, DFM supplementation improved faecal score and resulted in less fetid faeces $(P<0.001)$. DFM inclusion reduced $(P<0.05)$ the biogenic amines concentration: putrescine, spermidine and cadaverine, besides the concentration of phenols and quinoline.

Conclusions: The use of $B$. subtillis and B. licheniformis as DFM reduce the concentration of nitrogen fermentation products in faeces and faecal odour, but the digestibility of nutrients is not altered in dogs.

Keywords: Biogenic amines, Direct-fed microbials, Faecal consistency, Intestinal functionality

\section{Background}

Many complete dog foods have a high protein content in their formulations, which can result in high concentrations of undigested nitrogen compounds in the large intestine, leading to the formation of putrefactive compounds. These compounds include ammonia, biogenic amines, branched-chain fatty acids, sulphidric gas, phenols and indoles [1]. Some of these catabolites can negatively affect intestinal functionality, contributing to inflammatory processes, such as colitis and colon

\footnotetext{
*Correspondence: tais.sbastoss@gmail.com

'Department of Animal Science, Federal University of Paraná, Curitiba 80035-050, Brazil

Full list of author information is available at the end of the article
}

carcinogenesis, as well as the worsening of dogs' faecal odour $[1,2]$. Furthermore, the increase in the nondigestible-protein flow that reaches the colon provides fermentation substrates to organisms with pathogenic potential, such as Clostridium, Salmonella and Escherichia species [3, 4], and can contribute to dysbiosis, an imbalance of the intestinal microbiota.

Thus, the search for nutritional strategies, such as the use of direct-fed microbials (DFM) to improve dogs' intestinal functionality and faecal quality is extremely relevant. DFM has been defined by the US Food and Drug Administration as the feed product containing the source of naturally-existing live microbes, like some bacteria of the Bacillus genus. When supplemented in the 
diet, these microorganisms may favour non-pathogenic bacteria [5, 6].

Bacteria of the Bacillus genus, such as the facultative anaerobic species B. subtillis and B. licheniformis, have the advantage of sporulation. This characteristic makes them more viable in food and resistant to acidic gastric $\mathrm{pH}[6-8]$. B. subtilis and B. licheniformis are commonly found as spores in the soil. The spores are dehydrated and when exposed to appropriate nutrients and moisture will germinate in the small intestine, resuming their cell vegetative growth [9]. After being excreted, these organisms can sporulate again in faeces $[7,10]$.

Studies have shown that $B$. subtilis and B. licheniformis can improve faecal odour and reduce gas formation in the intestine of dogs [11], prevent necrotic enteritis in broilers [12], and reduce diarrhoea in piglets [13]. Since they are viable after excretion, these organisms degrade organic matter in the faeces, reduce ammonia production [4] and potentially reduce faecal odour. Given the above, the aim of the present study was to evaluate diet digestibility, faecal characteristics and intestinal fermentation products in dogs supplemented with DFM Bacillus subtilis and Bacillus licheniformis.

\section{Results}

All dogs remained healthy throughout the experiment. No episodes of vomiting or diarrhoea were observed. No differences in DM intake (Control $=201.2+4.33 \mathrm{~g}$ / day and DFM $=204.1+5.34 \mathrm{~g} /$ day) and body weight (Control $=10.2+1.04 \mathrm{~kg}$ and DFM $=10.5+1.08 \mathrm{~kg})$ were observed between treatments $(P>0.05)$.

The inclusion of DFM with Bacillus subtilis and Bacillus licheniformis in extruded dog diets did not alter $(P>0.05)$ the nutrient apparent total tract digestibility (ATTD) coefficients and diet metabolisable energy (ME) (Table 1), faecal DM, ammonia, faecal $\mathrm{pH}$, and sialic acid (Table 2), as well as the SCFA and BCFA concentrations in the faeces (Table 3). The faecal score, however, was increased and the inclusion of DFM resulted in less fetid faeces both in

Table 1 Diet ATTD and ME means with or without DFM $(n=8)$

\begin{tabular}{lllll}
\hline Item & Control & DFM & SEM & P-value \\
\hline ATTD (\%) & & & & \\
Dry matter & 79.1 & 78.8 & 0.31 & 0.739 \\
Organic matter & 84.1 & 83.8 & 0.25 & 0.754 \\
Crude protein & 79.9 & 78.8 & 0.56 & 0.281 \\
Ether extract & 86.5 & 85.6 & 0.42 & 0.297 \\
Ash & 43.9 & 44.2 & 0.45 & 0.921 \\
Nitrogen-free extract & 92.9 & 92.1 & 0.67 & 0.892 \\
ME (kcal/kg) & 4034.9 & 4062.4 & 10.49 & 0.199 \\
\hline ATID Appar
\end{tabular}

ATTD Apparent total tract digestibility, ME Metabolisable energy DFM Direct-fed microbials $\left(62.5 \mathrm{mg} / \mathrm{kg}\right.$ of diet of a mixture of $3.66 \times 10^{7} \mathrm{cfu} / \mathrm{kg}$ Bacillus subtilis and $3.66 \times 10^{7} \mathrm{cfu} / \mathrm{kg}$ Bacillus licheniformis)
Table 2 Faecal characteristics means of dogs fed diets with or without DFM $(n=8)$

\begin{tabular}{lllll}
\hline Item & Control & DFM & SEM & $P$-value \\
\hline Fresh faeces $\mathrm{pH}$ & 6.32 & 6.50 & 0.058 & 0.128 \\
After $6 \mathrm{~h} \mathrm{pH}$ & 6.32 & 6.31 & 0.035 & 0.933 \\
Fresh faeces moisture (\%) & 70.04 & 69.12 & 0.563 & 0.434 \\
After 6 h moisture (\%) & 67.39 & 67.36 & 0.707 & 0.981 \\
Fresh faeces ammonia $(\mathrm{g} / \mathrm{kg})$ & 0.52 & 0.50 & 0.001 & 0.834 \\
After 6 h ammonia $(\mathrm{g} / \mathrm{kg})$ & 0.73 & 0.61 & 0.001 & 0.897 \\
Faecal production & 0.13 & 0.12 & 0.005 & 0.379 \\
Sialic acid $(\mu$ mol $/ \mathrm{g})$ & 2.46 & 2.47 & 0.04 & 0.943 \\
\hline
\end{tabular}

DFM Direct-fed microbials $\left(62.5 \mathrm{mg} / \mathrm{kg}\right.$ of diet of a mixture of $3.66 \times 10^{7} \mathrm{cfu} / \mathrm{kg}$ Bacillus subtilis and $3.66 \times 10^{7} \mathrm{cfu} / \mathrm{kg}$ Bacillus licheniformis)

fresh samples and $6 \mathrm{~h}$ after defecation $(P<0.05$, Table 4 and Fig. 1). According to $82 \%$ of the evaluators, fresh faeces of dogs consuming the DFM diet were less fetid than those from animals consuming the control diet. Similarly, $78 \%$ of evaluators considered that $6 \mathrm{~h}$ after defecation the faeces of dogs consuming DFM were less fetid than those in the control group $(P<0.05$, Fig. 1$)$. The concentration of biogenic amines: putrescine, spermidine and cadaverine, as well as phenols and quinoline were reduced $(P<0.05)$ with the inclusion of DFM (Tables 5 and 6).

\section{Discussion}

This study demonstrates that dietary DFM supplementation reduced the concentration of protein fermentation compounds in faeces, resulting in lower faecal odour of dogs. However, it did not change diet digestibility.

The absence of DFM effects on diet digestibility components was similar to that observed by Biourge [14] and Pasupathy [15]. The authors found no difference in the digestibility of dog diets containing $7.5 \times 10^{6} \mathrm{cfu}$ of

Table 3 SCFA and BCFA means in faeces of dogs fed diets with or without DFM $(n=8)$

\begin{tabular}{lllll}
\hline Item & Control & DFM & SEM & $P$-value \\
\hline SCFA $(\mu \mathrm{mol} / \mathrm{g})$ & & & & \\
Acetic & 31.21 & 33.79 & 1.118 & 0.263 \\
Propionic & 27.66 & 27.16 & 1.205 & 0.845 \\
Butyric & 4.78 & 3.94 & 0.316 & 0.193 \\
Total SCFA & 64.33 & 64.89 & 1.899 & 0.887 \\
BCFA ( $\mu$ mol/g) & & & & \\
Isobutyric & 0.79 & 0.91 & 0.035 & 0.090 \\
Isovaleric & 0.78 & 0.67 & 0.044 & 0.198 \\
Valeric & 0.29 & 0.31 & 0.011 & 0.415 \\
Total BCFA & 1.94 & 1.87 & 0.065 & 0.640 \\
\hline SCFA short chan faty
\end{tabular}

SCFA short chain fatty acids, BCFA branched chain fatty acids DFM Direct-fed microbials $\left(62.5 \mathrm{mg} / \mathrm{kg}\right.$ of diet of a mixture of $3.66 \times 10^{7} \mathrm{cfu} / \mathrm{kg}$ Bacillus subtilis and $3.66 \times 10^{7} \mathrm{cfu} / \mathrm{kg}$ Bacillus licheniformis) 
Table 4 Faecal score, odour medians and interquartiles of dogs fed diets with or without DFM

\begin{tabular}{llll}
\hline Item & Control & DFM & $P$-value \\
\hline Faecal score & $4(3 / 4)$ & $4(4 / 4)$ & $<0.001$ \\
Odour fresh faeces & $2(2.0 / 2.0)$ & $1(1.0 / 1.0)$ & $<0.001$ \\
Odour after $6 \mathrm{~h}$ & $2(2.0 / 2.0)$ & $1(1.0 / 1.0)$ & $<0.001$ \\
\hline
\end{tabular}

Faecal score $(\mathrm{n}=8) 1$ (liquid stools) to 5 (dry stools); faecal odour $(\mathrm{n}=50) 1$ (less fetid than control) 2 (same as control) and 3 (more fetid than control) DFM (Direct-fed microbials) $\left(62.5 \mathrm{mg} / \mathrm{kg}\right.$ of diet of a mixture of $3.66 \times 10^{7} \mathrm{cfu} /$ $\mathrm{kg}$ Bacillus subtilis and $3.66 \times 10^{7} \mathrm{cfu} / \mathrm{kg}$ Bacillus licheniformis)

Bacillus CIP 5832 and $2 \times 10^{7}$ cfu of Lactobacillus acidophilus.

Besides nutrient digestibility, faecal characteristics should also be taken into consideration in dog-food evaluations. Faecal characteristics can be a reflex of intestinal functionality and have become more relevant for pet owners that look for dog foods that reduce faecal odour and improve faecal consistency. When compared to the control diet, the effect of DFM was reflected by an improvement in faecal consistency. These results were also reported by Félix et al. [6], using a $0.01 \%$ supplement of Bacillus subtilis (C-3102) and Paap et al. [11], using $0.5 \mathrm{~g} / 100 \mathrm{~g} \mathrm{Ba-}$ cillus subtilis (C-3102) in diets for dogs. Similarly, when supplement in diet Bacillus subtilis and Bacillus licheniformis, Alexopoulos et al. [13] reported a diarrhoea reduction in piglets.

The maintenance of intestinal eubiosis plus SCFA production in the colon can explain the increase in faecal consistency [16] with the use of probiotics and DFM in the diet. SCFA production by intestinal microorganisms and their absorption by the colonocytes stimulate water and electrolyte absorption, as well as increase the absorption rate of sodium, responsible for most of the water absorbed in the intestinal lumen [17]. Despite this, faecal SCFA concentration was not altered in the present study with the use of DFM. This may be due to the rapid absorption rate of SCFA by the intestinal mucosa $[1,18]$.

Likewise, no changes were observed in dogs' faecal $\mathrm{pH}$, in agreement with what has been reported by Swanson et al. [1], Félix et al. [6], and Stercova et al. [19]. On the other hand, Feliciano et al. [5] observed a reduction in faecal $\mathrm{pH}$ of dogs fed a diet containing Lactobacillus spp. The absence of faecal $\mathrm{pH}$ alterations of dogs fed with Bacillus spp. can be due to the limited ability of the Bacillus genus species to produce lactic acid when compared to Lactobacillus [6].

Amino acid fermentation catabolites are considered to be the main odoriferous components of faeces and can have negative influences on intestinal functionality due to their toxicity and their favouring the survival of bacteria with pathogenic potential [20-22]. Several putrefactive compounds can be produced from the fermentation of undigested amino acids by deamination, deamination-decarboxylation or carboxylation [23], with ammonia, biogenic amines, BCFA, indoles, phenols, and volatile compounds containing sulphur being the major groups [22, 23].

In the present study, DFM supplementation decreased the concentration of potentially toxic putrefactive compounds for the intestinal mucosa when in high concentrations. The reduced compounds were: putrescine, spermidine, cadaverine, phenols, and quinoline, which resulted in faeces with less odour, both when fresh and $6 \mathrm{~h}$ after defecation.

Besides these results, the faecal ammonia concentration was not reduced in dogs fed the diet containing DFM. Likewise, other studies did not report a same pattern among the increase or decrease of all protein catabolites $[1,3,24]$. This may be explained by the different nitrogen substrates that generate these catabolites and their different utilization rates by the gut microbiota. Ammonia is produced by deamination, while biogenic

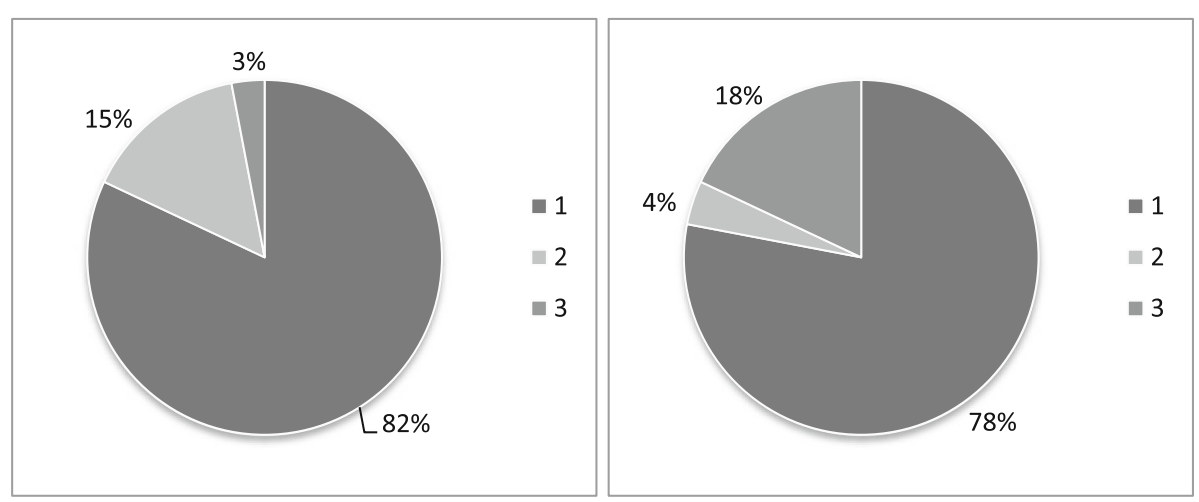

Fresh faeces

Faeces after 6 hours

Fig. 1 Points frequency of faecal odour scores attributed by evaluators $(n=50) .1=$ less fetid odour; $2=$ same odour and $3=$ more fetid odour, as compared to faeces of dogs fed the control diet 
Table 5 Biogenic amines $(\mathrm{mg} / \mathrm{kg})$ means in faeces of dogs fed diets with or without DFM $(n=8)$

\begin{tabular}{lllll}
\hline Item & Control & DFM & SEM & $P$-value \\
\hline Tiramine & 48.36 & 46.22 & 10.770 & 0.443 \\
Putrescine & 71.24 & 47.51 & 9.321 & 0.025 \\
Cadaverine & 129.87 & 88.63 & 18.935 & 0.050 \\
Histamine & 22.93 & 23.89 & 5.280 & 0.448 \\
Serotonin & 3.20 & 2.39 & 0.381 & 0.057 \\
Agmatine & 0.00 & 0.00 & 0.000 & 1.000 \\
Spermidine & 26.77 & 19.94 & 2.451 & 0.015 \\
Phenylethynamine & 0.55 & 0.92 & 0.253 & 0.147 \\
Tryptamine & 0.51 & 0.22 & 0.344 & 0.272 \\
Total amines & 303.42 & 209.90 & 38.301 & 0.031 \\
\hline
\end{tabular}

DFM Direct-fed microbials $\left(62.5 \mathrm{mg} / \mathrm{kg}\right.$ of diet of a mixture of $3.66 \times 10^{7} \mathrm{cfu} / \mathrm{kg}$ Bacillus subtilis and $3.66 \times 10^{7} \mathrm{cfu} / \mathrm{kg}$ Bacillus licheniformis)

amines, phenols, and indoles are produced by the decarboxylation of amino acids. The amine putrescine, spermidine and cadaverine are produced from the decarboxylation of ornithine, methionine and lysine, respectively [25]. Phenols and indoles are produced from the fermentation of tyrosine and tryptophan, respectively [26]. Since these mechanisms are mediated by enzymes produced mainly by intestinal bacteria with pathogenic potential, it is possible that DFM influenced the intestinal microbiota, favouring the non-pathogenic bacterial population.

The fact that the odour was still low $6 \mathrm{~h}$ after defecation (simulating what usually happens in the home environment) indicates that $B$. subtillis and B. licheniformis have a continuous action in faeces after excretion. According to Vainshtein et al. [4], spore-forming Bacillus species produce substances that are antagonists to the development of organisms with pathogenic potential (generally proteolytic) and produce enzymes that degrade $\mathrm{OM}$ present in the excreta, reducing ammonia production. These effects can occur both in the gut and the faeces. Still according to these authors, Bacillusgenus bacteria have shown major results in sanitizing poultry and swine waste.

Table 6 Mean percentage of peak areas of more abundant volatile organic compounds present in the dogs' faeces $(n=8)$

\begin{tabular}{llllll}
\hline & Item & Control & DFM & SEM & P-value \\
\hline Fresh faeces & Phenols & 37.18 & 18.96 & 3.13 & $<0.001$ \\
& Quinoline & 14.57 & 3.06 & 3.14 & $<0.001$ \\
& Indoles & 63.32 & 67.08 & 2.98 & 0.548 \\
\multirow{3}{*}{ After 6 h } & Phenols & 33.48 & 34.58 & 2.86 & 0.855 \\
& Quinoline & 7.68 & 7.33 & 1.85 & 0.927 \\
& Indoles & 58.83 & 58.04 & 3.98 & 0.929
\end{tabular}

DFM (Direct-fed microbials) $62.5 \mathrm{mg} / \mathrm{kg}$ of diet of a mixture of $3.66 \times 10^{7} \mathrm{cfu} /$ $\mathrm{kg}$ Bacillus subtilis and $3.66 \times 10^{7} \mathrm{cfu} / \mathrm{kg}$ Bacillus licheniformis)
Another mechanism that may have contributed to the intestinal microbiota balance could be the immunomodulatory action of B. subtillis and B. licheniformis in the gut [27], reducing the establishment of organisms with pathogenic potential, protecting the villi and the absorption surface against irritating toxins [28], such as biogenic amines, phenols and indoles. In a study with broilers, Knap et al. [12] observed that the use of Bacillus licheniformis in the diet helped prevent necrotic enteritis.

Considering the discussion above, dietary supplementation with DFM B. subtilis and B. licheniformis has potential beneficial effects in gut functionality in dogs. To our knowledge, this was the first study to describe the reduction on biogenic ammines, phenols, and quinoline in faeces of dogs fed DFM. Besides, the reduction of the faecal odour and improvement in the faecal score are very important commercial characteristics, considering the close relation between dogs and their owners. Different from conventional probiotics, these DFM may be more effective in reaching the colon, considering their ability to form spores and resist to environment and gastric $\mathrm{pH}$ levels $[7,8]$. These characteristics make DFM very interesting for practical applications in commercial dog diets.

Despite these potential benefits, one limitation of the present study was that we did not evaluate the faecal microbiota of dogs. Besides, although many studies report the toxic effects of higher concentrations of nitrogen fermentative products to colonocytes [20-22], we still have a lack of information of which is the limit between the functional and toxic concentrations of these compounds in the gut mucosa of dogs. This is important considering that dogs have greater protein requirements than humans and it was previously reported that the modulation of some polyamines is important to reduce inflammatory processes and cell infiltrations in dogs with inflammatory bowel disease and colonic polyps [29]. Thus, further studies evaluating the effects of DFM supplementation in faecal microbiota and nitrogen fermentative products in dogs are required to better understand their effects on intestinal functionality and the modulation of dogs' intestinal microbiota.

\section{Conclusions}

The inclusion of $3.66 \times 10^{7} \mathrm{cfu} / \mathrm{kg}$ of Bacillus subtilis feed and $3.66 \times 10^{7} \mathrm{cfu} / \mathrm{kg}$ of Bacillus licheniformis feed in extruded dog diets improves faecal consistency and odour. It also reduces faecal concentration of compounds produced in protein catabolism such as putrescine, spermidine, cadaverine, phenols, and quinoline, demonstrating possible beneficial effects on dog's intestinal functionality. 


\section{Methods}

\section{Animals and housing}

Sixteen adult intact beagle dogs were used (eight males and eight females), with an average body weight of $10.3+1.07 \mathrm{~kg}$ and 4 years of age. All animals underwent previous clinical and physical examinations, were vaccinated, dewormed, and individually housed in covered brickwork kennels ( $5 \mathrm{~m}$ long $\times 2 \mathrm{~m}$ wide), containing a bed and free access to fresh water. The environment temperature ranged from $16^{\circ} \mathrm{C}$ to $28^{\circ} \mathrm{C}$ with a $12-\mathrm{h}$ light-dark cycle (light $6 \mathrm{am}-6 \mathrm{pm}$ ). All animals were brought to the Research laboratory on canine nutrition of the Federal University of Parana (Curitiba, PR, Brazil) from Maiorca Kennel (Colombo, PR, Brazil) when they were 3-4 months old.

During most of the diet adaptation period (until the 16th day) dogs had free supervised access to an outdoor area for $2 \mathrm{~h}$ a day. Between days 17-25 the dogs were individually housed at the kennels to allow for faecal collection. All dogs received extra attention and kennel enrichment during this period. The dogs will be donated when they complete 6 years of age. The use of animals for this study was approved by the Ethics Committee on Animal Use from the Agrarian Sciences Sector, Federal University of Paraná, Curitiba, PR, Brazil (012/2019).

\section{Experimental diets}

The same commercial diet for adult dogs was divided into two parts and used in the experimental treatments. One part (eight dogs, four males and four females) was used in the control treatment, with no DFM supplementation, and the other part (eight dogs, four males and four females) was used as the test treatment containing $62.5 \mathrm{mg} / \mathrm{kg}$ of a diet with a mixture of Bacillus subtilis $\left(3.66 \times 10^{7} \mathrm{cfu} / \mathrm{kg}\right.$ of the diet) and Bacillus licheniformis $\left(3.66 \times 10^{7} \mathrm{cfu} / \mathrm{kg}\right.$ of the diet) as DFM (PureGro ${ }^{\oplus}$, DSM, Heerlen Netherlands). The diet had the following composition: poultry viscera meal, meat meal, corn, soybean meal, poultry fat, swine liver hydrolysate, sodium chloride, citric acid, antioxidants (BHT, BHA), propionic acid, vitamin $A$, vitamin $D 3$, vitamin $E$, vitamin $B 1$, vitamin B6, vitamin B12, vitamin $\mathrm{K} 3$, nicotinic acid, folic acid, biotin, calcium pantothenate, zinc sulfate, calcium iodate, sodium selenite, copper sulfate, iron sulfate, manganese sulfate and zinc oxide. The chemical composition of the experimental diets is shown in (Table 7).

DFM was diluted in poultry viscera oil and used on top of the test diet. The same amount of oil, without DFM, was used on the control treatment, ensuring that the diets were isonutritive.

\section{Experimental procedures}

The digestibility assay followed the total faeces collection method as recommended by the Association of
Table 7 Analysed chemical composition of the experimental diets (dry matter basis, \%)

\begin{tabular}{lll}
\hline Item & Control & DFM \\
\hline Dry matter & 91.77 & 91.51 \\
Crude protein & 21.75 & 21.12 \\
Ether extract in acid hydrolysis & 9.22 & 9.04 \\
Ash & 7.02 & 7.00 \\
Crude fibre & 2.23 & 2.42 \\
Calcium & 1.18 & 1.23 \\
Phosphorus & 0.89 & 0.91 \\
\hline
\end{tabular}

DFM Direct-fed microbials $\left(62.5 \mathrm{mg} / \mathrm{kg}\right.$ of a diet with a mixture of $3.66 \times 10^{7}$ $\mathrm{cfu} / \mathrm{kg}$ Bacillus subtilis and $3.66 \times 10^{7} \mathrm{cfu} / \mathrm{kg}$ of Bacillus licheniformis)

American Feed Control Official [30]. The diets were provided during a 20-day adaptation period, followed by 5 days of total faeces collection, resulting in a mixture of faeces from each animal.

The food was provided twice a day (8:30 a.m. and 4:00 p.m.), in amounts sufficient to meet the animal's metabolisable energy (ME) requirement according to the National Research Council [31], where: ME (kcal/day) = 130 $\mathrm{x}$ Body weight ${ }^{0.75}$. Water was provided ad libitum. The faeces were collected and weighed at least two times per day and stored in individual previously-identified plastic containers, covered and stored in a freezer $\left(-14{ }^{\circ} \mathrm{C}\right)$ to be analysed later.

At the end of the collection period, the faeces of each replicate were thawed at room temperature and homogenized separately, forming a composite sample from each animal. Faeces were dried in a forced ventilation oven (320-SE, Fanem, São Paulo, Brazil) at $55^{\circ} \mathrm{C}$ for $48 \mathrm{~h}$ or until reaching constant weight. Diets and faeces were ground to $1.0 \mathrm{~mm}$ in a hammer mill (Arthur H. Thomas Co., Philadelphia, PA, USA), using $1.0-\mathrm{mm}$ wire mesh sieves for the bromatological testing (in duplicate and with repetitions when the variation was higher than $5 \%$ ).

The amounts of dry matter at $105^{\circ} \mathrm{C}$ (DM105), crude protein (CP, method 954.01), crude fibre (CF, method 994.13), ether extract in acid hydrolysis (EEAH, method 954.02), and ash (942.05) were determined in both diets and faeces according to the Association of the Official Analytical Chemists [32]. The amount of gross energy (GE) was established using a calorimetric pump (Parr Instrument Co., model 1261, Moline, IL, USA), and organic matter $(\mathrm{OM})$ was calculated by the difference between 100 - Ash. Nitrogen-free extract was calculated as 100 - CP - Ash - CF - EEAH.

Faecal characteristics were assessed at the end of the study by analysing the total amount of dry faecal matter (DMf), faeces production (g faeces/g DM intake/5 days), consistency score and odour, $\mathrm{pH}$, ammonia concentration, short-chain fatty acids (SCFA), branched-chain 
fatty acids (BCFA), phenols, indoles, sialic acid, and biogenic amines.

Considering that the faecal-consistency scoring system is a subjective evaluation, the sample was always evaluated by the same researcher using a 5 -point rating scale: $1=$ faeces are soft and have no defined shape; $2=$ faeces are soft and poorly formed; $3=$ faeces are soft, formed and moist; 4 = faeces are well formed and consistent; 5 = faeces are well formed, hard and dry, according to Carciofi [33].

Faecal odour was evaluated and scored on the 25th day of the experimental period. Faeces from three animals per treatment were randomly collected, homogenized and the same amounts $(5.0 \mathrm{~g})$ were placed in plastic containers of the same size and covered with plastic film with holes (same number and size). The containers were classified as: A (control diet) and B (DFM diet), so the participants would not have information about the treatment. The sensorial analysis was performed by 50 evaluators with fresh faeces (up to $30 \mathrm{~min}$ after defecation) and 6 hours after defecation, with different people at each point in time. In the evaluation, sample B with DFM was compared to A (control diet) using the following scoring system: $1=$ better odour than control (less fetid); 2 = same as control; 3 = worse than control (more fetid).

Faecal $\mathrm{pH}$ and ammonia concentrations were analysed in faeces collected up to $15 \mathrm{~min}$ after defecation. Faecal $\mathrm{pH}$ was measured in a digital $\mathrm{pH}$ meter (331, Politeste Instrumentos de Teste Ltda, São Paulo, SP, Brazil) using $3.0 \mathrm{~g}$ of fresh faeces diluted in $30 \mathrm{~mL}$ of distilled water. The ammonia concentration was determined according to the method described by Brito et al. [34].

Fresh faeces collected up to $15 \mathrm{~min}$ after defecation were used to determine SCFA and BCFA. A properly labelled plastic container with a lid was used to weigh $10 \mathrm{~g}$ of faeces mixed with $30 \mathrm{~mL}$ of $16 \%$ formic acid. This mixture was homogenized and stored at $4{ }^{\circ} \mathrm{C}$ for 3 to 5 days. Before the analysis, these solutions were centrifuged at $5000 \mathrm{rpm}$ (2 K15 centrifuge, Sigma, Osterodeam Hans, Germany) for $15 \mathrm{~min}$. At the end, the supernatant was separated and centrifuged. Each sample underwent three centrifugations and, at the end of the last one, part of the supernatant was transferred to a properly identified eppendorff for subsequent freezing. Later on, the samples were thawed and centrifuged again at 14000 rpm for 15 min (Rotanta 460 Robotic, Hettich, Tuttlingen, Germany). Faecal SCFA and BCFA were determined by gas chromatography (Shimadzu', model GC2014, Kyoto, Japan) using a 30-m long and 0.32-mm wide glass column (Agilent Tecnologias, HP INNO cera19,091 N, Santa Clara, USA). Nitrogen was used as the carrier gas at a $3.18 \mathrm{~mL} / \mathrm{min}$ flow rate. Working temperatures were $200^{\circ} \mathrm{C}$ at injection, $240^{\circ} \mathrm{C}$ in the column (at a $20^{\circ} \mathrm{C} / \mathrm{min}$ rate), and $250^{\circ} \mathrm{C}$ in the flame ionization detector.
Phenols and indoles were analysed by chromatography using a GCMS2010 Plus gas chromatographer $\left(\right.$ Shimadzu ${ }^{\circ}$ ) coupled to a TQ8040 mass spectrometer with an AC 5000 autosampler and a split-splitless injector. Chromatographic separations were obtained in the SH-Rtx-5MS $\quad(30 \mathrm{~m} \times 0.25 \mathrm{~mm} \times 0.25 \mu \mathrm{m} \quad$ Shimadzu ${ }^{\circ}$ column with a $1.0-\mathrm{mL} \mathrm{min}^{-1}$ flow rate, and helium as the drag gas at a 5.0 rate. The transfer line and ionization source temperatures were maintained at $40^{\circ} \mathrm{C}$ and $220^{\circ} \mathrm{C}$, respectively, with the 1 - $\mathrm{L}$ injection volume in the split mode (1:10 rate). The GC oven temperature was maintained at $220^{\circ} \mathrm{C}(5 \mathrm{~min})$ with a $40^{\circ} \mathrm{C} / \mathrm{min}^{-1}$ increase to $280^{\circ} \mathrm{C}(5 \mathrm{~min})$. Total analysis time was $31 \mathrm{~min}$ and the mass spectrometer operated in the full scan modes $(\mathrm{m} / \mathrm{z}=40$ to 400$)$ and selective ion monitoring (SIM), with electron ionization at $70 \mathrm{eV}$. GCMSsolution $^{\circ}$ was the software used in the data analysis.

For the sialic acid determination, faeces were lyophilized (Alpha 1-4 LO plus, Christ, Osterodeam Hans, Germany) and analysed according to the method described by Jourdian et al. [35]. Biogenic amines were analysed according to the method described by Urrego et al. [36] in fresh faeces, collected up to $15 \mathrm{~min}$ after defecation.

The DMf, consistency score, faecal odour, $\mathrm{pH}$, ammonia, phenols and indoles were also analysed in the same samples $6 \mathrm{~h}$ after defecation. For the analysis performed $6 \mathrm{~h}$ after defecation, faeces were maintained at room temperature (average of $24.5^{\circ} \mathrm{C}, 84 \%$ relative air humidity and in the shade for $6 \mathrm{~h}$.)

\section{Calculations and statistical analyses}

Based on the laboratory results, the apparent total tract digestibility (ATTD) coefficients and the diet's ME were calculated according to the Association of American Feed Control Official [30]:

$\mathrm{ATTD} \%=[(\mathrm{g}$ of nutrient intake $-\mathrm{g}$ of nutrient excretion $) / g$ of nutrient intake] $\times 100$.

$\mathrm{ME}(\mathrm{kcal} / \mathrm{g})=\{\mathrm{kcal} / \mathrm{g}$ GE intake $-\mathrm{kcal} / \mathrm{g}$ GE faecal excretion - [(g CP intake - g CP.

faecal excretion) $\times 1.25 \mathrm{kcal} / \mathrm{g}]\} / \mathrm{g}$ of feed intake.

The experiment had a completely randomized design with two treatments, each one with eight replicates, except for faecal odour that had 50 replicates. Each dog was considered an experimental unit. The Shapiro-Wilk test was used to determine normality of the data and the homoscedasticity of variances was analysed by Bartlett's test. When these assumptions were met, the $t$-Student's test was used at a $5 \%$ significance level. The non-parametric data were analysed by the Mann-Whitney-Wilcoxon test $(P<0.05)$. The frequency of faecal odour scores was analysed by the chi-square test $(P<0.05)$. 


\section{Abbreviations}

DFM: Direct-fed microbials; ME: Metabolisable energy; CP: Crude protein; EEAH: Ether extract in acid hydrolysis; DM: Dry matter; DMf: Dry faecal matter; GE: Gross energy amount; OM: Organic matter; SCFA: Short-chain fatty acids; BCFA: Branched-chain fatty acids; ATTD: Apparent total tract digestibility coefficients

\section{Acknowledgements}

The authors thank DSM for supporting the research.

\section{Authors'contributions}

APF, LCB, SGO and AM designed and supervised the study, carried out data analyses and reviewed the manuscript. DCL, TSB and CMMS conducted the research and carried out laboratory analyses. DCL and TSB interpreted data and wrote the manuscript draft. LCB, assisted in the translation of the manuscript. All authors have read and approved the final manuscript.

\section{Funding}

The project was supported by DSM São Paulo, SP, Brazil. The funding was important to pay for the experimental diets and laboratory analyses but did not interfere in data interpretation and in writing the manuscript.

\section{Availability of data and materials}

All data generated or analysed during this study will be available from the corresponding author upon reasonable previous request and with the permission of the DSM.

\section{Ethics approval and consent to participate}

The experiment was approved by the Ethics Committee on Animal Use from the Agrarian Sciences Sector, Federal University of Paraná, Curitiba, PR, Brazil, under protocol number 012/2019.

\section{Consent for publication}

Not applicable.

\section{Competing interests}

The authors declare that they have no competing interests.

\section{Author details}

'Department of Animal Science, Federal University of Paraná, Curitiba 80035-050, Brazil. ²DM, São Paulo, SP, Brazil.

\section{Received: 30 October 2019 Accepted: 19 March 2020 \\ Published online: 19 April 2020}

\section{References}

1. Swanson KS, Grieshop CM, Flickinger EA, Bauer LL, Healy HP, Dawson KA, Fahey GC. Supplemental fructooligosaccharides and mannanoligosaccharides influence immune function, ileal and total tract nutrient digestibilities, microbial populations and concentrations of protein catabolites in the large bowel of dogs. J Nutr. 2002;132:980-89. https://doi. org/10.1093/jn/132.5.980

2. Wollowski I, Rechkemmer G, Pool BLZ. Protective role of probiotics and prebiotics in colon cancer. Am J Clin Nutr. 2001;73:451s-55s. https://doi.org/ 10.1093/ajcn/73.2.451s

3. Barry KA, Wojcicki BJ, Middelbos IS, Vester BM, Swanson KS, Fahey GC. Dietary cellulose, fructooligosaccharides, and pectin modify faecal protein catabolites and microbial populations in adult cats. J Anim Sci. 2010;88: 2978-87. https://doi.org/10.2527/jas.2009-2464.

4. Vainshtein M Probiotics for environmental sanitation: goals and examples. Curr Environ Issues Challenges. 2014;127:35. https://doi.org/10.1007/ BF00264683.

5. Feliciano MAR, Saad FMOB, Logato PVR, Aquino AA, José VA, Roque NC. Effects of probiotics on digestibility, faecal score, and haematologic characteristics in dogs. Arq Bras Med Vet Zootec. 2009;61:1268-74. https:// doi.org/10.1590/S0102-09352009000600003.

6. Félix AP, Netto MVT, Murakami FY, Brito CBMD, Oliveira SGD, Maiorka A. Digestibility and faecal characteristics of dogs fed with Bacillus subtilis in diet. Ciênc Rural. 2010;40:2169-73. https://doi.org/10.1590/S010384782010005000166 .
7. Hoa NT, Baccigalupi L, Huxham A, Smertenko A, Van PH, Ammendola S, Cutting SM. Caracterização de espécies de Bacillus utilizadas para bacterioterapia oral e bacterioprofilaxia de desordens gastrintestinais. Appl Environ Microbiol. 2000;66:5241-47. https://doi.org/10.1128/AEM.66.12.52415247.2000.

8. Coppola MDM, Gil-Turnes C. Probiotics and immune response. Ciênc Rural. 2004;34:1297-303. https://doi.org/10.1590/S0103-84782004000400056.

9. Moir A. How do spores germinate?. J Appl Microbiol. 2006;101:526-30. https://doi.org/10.1111/j.1365-2672.2006.02885.x.

10. Tam NK, Uyen NQ, Hong HA, Duc LH, Hoa TT, Serra CR, Cutting SM. O ciclo de vida intestinal de Bacillus subtilis e parentes próximos. J Bacteriol. 2006; 188:2692-700. https://doi.org/10.1128/JB.188.7.2692-2700.2006.

11. Paap PM, Laak VDL, Smit JI, Nakamura N, Beynen AC. Administration of Bacillus subtilis C-3102 (Calsporin ${ }^{\oplus}$ ) may improve faeces consistency in dogs with chronic diarrhea. Res Opin Anim Vet Sci. 2016;6:256-60. https://doi.org/ 10.20490/ROAVS/16-043.

12. Knap I, Lund B, Kehlet AB, Hofacre C, Mathis G. Bacillus licheniformis prevents necrotic enteritis in broiler chickens. Avian Dis. 2010;54:931-35. https:/doi. org/10.1637/9106-101509-ResNote.1.

13. Alexopoulos C, Georgoulakis IE, Tzivara A, Kyriakis CS, Govaris A, Kyriakis SC. Avaliação de campo do efeito de esporos de Bacillus licheniformis e Bacillus subtilis contendo probióticos sobre o estado de saúde, desempenho e qualidade de carcaça de suínos produtores e suínos. J Med Vet. 2004;51: 306-12. https://doi.org/10.1111/j.1439-0442.2004.00637.x.

14. Biourge V, Vallet $C$, Levesque $A$, Sergheraert R, Chevalier S, Roberton JL. The use of probiotics in the diet of dogs. J Nutr. 1998;128:2730S-32S. https://doi. org/10.1093/jn/128.12.2730S.

15. Pasupathy K, Sahoo A, Pathak NN. Effect of lactobacillus supplementation on growth and nutrient utilization in mongrel pups. Archiv Fur Tierernaehr. 2001;55:243-53. https://doi.org/10.1080/17450390109386195.

16. Suchodolski JS. Diagnóstico e interpretação da disbiose intestinal em cães e gatos. Vet J. 2016;215:30-7. https://doi.org/10.1016/j.tvj.2016.04.011.

17. Guarner F, Malagelada, JR. Flora intestinal na saúde e na doença. Lancet. 2003;361:512-19. https://doi.org/10.1016/S0140-6736(03)12489-0.

18. Von Engelhardt W, Burmester M, Hansen K, Becker G. Unidirectional fluxes of short-chain fatty acids across segments of the large intestine in pig, sheep and pony compared with Guinea pig. J Comparative Physiol B. 1995; 165:29-36. https://doi.org/10.1007/BF00264683.

19. Stercova E, Kumprechtova D, Auclair E, Novakova J. Effects of live yeast dietary supplementation on nutrient digestibility and faecal microflora in beagle dogs. J Anim Sci. 2016;94:2909-18. https://doi.org/10.2527/jas.2016-0584.

20. Zentek J, Marquart B, Pietrzak T, Ballevre O, Rochat F. Dietary effects on bifidobacteria and Clostridium perfringens in the canine intestinal tract. J Anim Physiol Anim Nutr. 2003:87:397-407. https://doi.org/10.1046/j.09312439.2003.00451.x

21. Suchodolski JS. Companion animals symposium: microbes and gastrointestinal health of dogs and cats. J Anim Sci. 2011;89:1520-30. https://doi.org/10.2527/jas.2010-3377.

22. Celi P, Verlhac V, Calvo EP, Schmeisser J, Kluenter AM. Biomarkers of gastrointestinal functionality in animal nutrition and health. Anim Feed Sci Technol. 2019;250:9-31. https://doi.org/10.1016/j.anifeedsci.2018.07.012.

23. Macfarlane $\mathrm{GT}$, Cummings $\mathrm{JH}$. The colonie flora, fermentation and large bowel digestive function. In: Phillips, SF, Pemberton JH, Shorter RG, (Eds.). The Large Intestine: Physiology, Pathophysiology and Disease. Raven Press, New York, NY; 1991. p. 51-92.

24. Peixoto MC, Ribeiro ÉM, Maria APJ, Loureiro BA, Santo LG, Putarov TC, Yoshitoshi FN, Pereira GT, Sá LRM, Carciofi AC. Effect of resistant starch on the intestinal health of old dogs: fermentation products and histological features of the intestinal mucosa. J Anim Physiol Anim Nutr. 2018;102:e11121. https://doi.org/10.1111/jpn.12711.

25. Neis $\mathrm{E}$, Dejong $\mathrm{C}$, Rensen $\mathrm{S}$. The role of microbial amino acid metabolism in host metabolism. Nutrients. 2015;7:2930-46. https://doi.org/10.3390/ nu7042930.

26. Garner CE, Smith S, Lacy CB, White P, Spencer R, Probert CS, Ratcliffe NM. Volatile organic compounds from faeces and their potential for diagnosis of gastrointestinal disease. The FASEB J. 2007;21:1675-88. https://doi.org/10. 1096/fj.06-6927com.

27. Leser TD, Knarreborg A, Worm J. Germination and outgrowth of Bacillus subtilis and Bacillus licheniformis spores in the gastrointestinal tract of pigs. J Appl Microbiol. 2008;104:1025-33. https://doi.org/10.1111/j.1365-2672.2007. 03633.x. 
28. Nicoli JR, Vieira LQ. Probióticos, prebióticos e simbióticos - Moduladores do ecossistema digestivo. Ciênc Hoje. 2000; 28:34-8.

29. Rossi G, Cerquetella M, Scarpona S, Pengo G, Fettucciari K, Bassotti G, Jergens A.E, Suchodolski J.S. Effects of probiotic bacteria on mucosal polyamines levels in dogs with IBD and colonic polyps: a preliminary study. Benef Microbes. 2018; 9: 247-55. https://doi.org/10.3920/BM2017.0024

30. Association of American Feed Control Officials (AAFCO). Dog and cat nutrient profiles. Official Publications of the Association of American Feed Control Officials Incorporated. AAFCO, Oxford, IN, USA; 2004.

31. National Research Council Committee on Dog and Cat Nutrition (NRC). Nutrient Requirements of Dogs and Cats. Washington, DC: National Academies Press; 2006

32. Association of the Official Analytical Chemists (AOAC). Official Methods of Analysis, 16th ed. AOAC, Washington, DC, USA; 1995.

33. Carciofi AC, Oliveira L, Valério A, Borges LL, Carvalho F, Brunetto MA, Vasconcellos RS. Comparison of micronized whole soybeans to common protein sources in dry dog and cat diets. Anim Feed Sci Technol. 2009;151: 251-60. https://doi.org/10.1016/j.anifeedsci.2009.01.002.

34. Brito CBM, Félix AP, Jesus RM, França MI, de Oliveira SG, Krabbe EL, Maiorka A. Digestibility and palatability of dog foods containing different moisture levels, and the inclusion of a mould inhibitor. Anim Feed Sci Technol. 2009; 159:150-5. https://doi.org/10.1016/i.anifeedsci.2010.06.001.

35. Jourdian G, Dean L, Roseman S. A periodate-resorcinol method for the quantitative estimation of free siálico acids and their glycosides. J Biol Chem. 1971; 246:430-5.

36. Urrego MIG, Matheus LFDO, Santos KM, Ernandes MC, Monti M, Souza DF, Brunetto MA. Effects of different protein sources on fermentation metabolites and nutrient digestibility of brachycephalic dogs. J Nutr Sci. 2017. p 6. https://doi.org/10.1017/jns.2017.46.

\section{Publisher's Note}

Springer Nature remains neutral with regard to jurisdictional claims in published maps and institutional affiliations.

Ready to submit your research? Choose BMC and benefit from:

- fast, convenient online submission

- thorough peer review by experienced researchers in your field

- rapid publication on acceptance

- support for research data, including large and complex data types

- gold Open Access which fosters wider collaboration and increased citations

- maximum visibility for your research: over $100 \mathrm{M}$ website views per year

At $\mathrm{BMC}$, research is always in progress.

Learn more biomedcentral.com/submissions 